\title{
Crime Prevention Policy Through Depriving Illicit Enrichment and Unexplained Wealth
}

\author{
Ermaida Ermaida ${ }^{1}$ Sonata Lukman ${ }^{2}$ \\ ${ }^{1.2}$ Universitas Hasanuddin \\ Makassar, Indonesia \\ ermaidaeffendi@gmail.com
}

\begin{abstract}
Crimes with economic motives are very detrimental to the state and have implications for national development. The assets of crime are the "blood of evil" for the continuation of the crime itself. The existing law enforcement facilities in Indonesia are still actor-oriented conventional. Conventional confiscation of assets depends on the guilt or responsibility (criminal) of the defendant with material quality, the burden of proof is quite complicated and heavy, namely there must be strong evidence and without the slightest doubt (beyond reason / negative wettelijk) so that difficulties occur and require a long time. quite a long time in asset confiscation because criminal assets can be changed, lost or destroyed and difficult to trace. The research method used in this research is normative legal research. The expected result of this research is the existence of a criminal law policy or criminal law politics in tackling criminal acts related to property crimes by establishing regulations regarding the confiscation of Non Conviction Based (NCB) property (in rem).
\end{abstract}

Keywords- Illicit Enrichment, Unexplained Wealth, NonConviction Based (NCB) Asset Forfeiture.

\section{INTRODUCTION}

Development in the context of the state is always aimed at improving the standard of living and welfare of the people in a better and more equitable direction. Sustainable development does not only concentrate on environmental issues because the progress of a nation can only be achieved by carrying out development in all fields including the legal field.

The problem of law enforcement is one of the big problems that requires serious handling in addition to the problems of national integration and economic recovery. Many people think that there is no connection between the three. In fact, there is a very close relationship between national integration, economic recovery, and law enforcement. Countries that can guarantee economic growth and national integration are those that can carry out law enforcement well.[1]

Successful implementation requires policy and planning. The starting point of development starts from actions to reduce problems with the aim of meeting needs and improving them to reach a reasonable level.

Nowadays, crime is very rampant with economic or profit motives which is very detrimental to the state which has implications for national development. Crime assets are the "blood of the crime" for the continuation of the crime itself. On the other hand, the existing law enforcement facilities in Indonesia are still actor-oriented conventional (following the suspect/criminal forfeiture in the criminal justice system). Conventional confiscation of assets depends on the guilt or responsibility (criminal) of the defendant with material quality, the burden of proof is quite complicated and heavy, namely there must be strong evidence and without the slightest doubt (beyond reason/negative wettelijk) so that difficulties occur and require sufficient time. long time in asset confiscation because criminal assets can be changed, lost or destroyed and difficult to trace. Even though Indonesia has a money laundering law, the evidence is still conventional. Even because the person in question still has property, the perpetrator who has been sentenced can still control the crime from the Correctional Institution, as in the case of Freddy Budiman (a drug dealer who was sentenced to death).

For this reason, the author views the need for a breakthrough or improvement in unconventional legal rules (regulations) through following the money (not on the perpetrators) in the context of illicit enrichment or unexplained wealth with Non-Conviction Based/NCB Asset Forfeiture (in rem) The Illicit Enrichment was introduced at the United Nations Against Corruption (UNCAC) in 2003 and Indonesia ratified it in 2006, but so far the regulation in Indonesia has not materialized.[2]

But on the other hand, although the push to regulate illicit enrichment or unexplained wealth with NonConviction Based ( $\mathrm{NCB}$ ) asset seizure mechanisms in overcoming criminal assets continues, it must be remembered that these provisions must not conflict with human rights, both in the context of personal protection, family and property that are under his control as part of the possible abuse of power from law enforcement.

With these considerations, it is interesting to conduct further research to obtain answers to the problems that exist in the confiscation of criminal assets, both in terms of existing regulations and the reality of the implementation of the confiscation of criminal property, including policies on draft regulations in the future in crime prevention. It is hoped that with this research, the concept and mechanism of Non Conviction Based (NCB) asset seizure (in rem) can be obtained, both from the aspect of certainty (rechtssicherheit), justice (gerechtigkeit) and legal benefits (zweckmassigheit) while 
still prioritizing the values contained in human rights. So that sustainable country development can be achieved in a better direction.[3]

\section{RESEARCH METHOD}

This research is a legal research, the types of research are normative research (legal research) and sociological juridical (social legal research).[4] The type of approach used in this research is a conceptual approach which is equipped with a case approach and a comparative approach.[5]

\section{FINDINGS AND DISCUSSION}

\section{The regulation of the seizure of criminal assets in the justice system in Indonesia}

The problem of substance and law enforcement in Indonesia has long been a serious problem for people seeking justice. To respond to this, many groups, especially legal experts, have agreed that there is a need for reform of the law itself, including provisions related to crime prevention, one of which is the renewal of criminal law by forming the Criminal Code (KUHP) whose contents include, among others, the principles of criminal law and criminal law material law provisions. Policies to make good criminal law regulations essentially cannot be separated from the purpose of crime prevention. Policies or politics of criminal law are also part of criminal politics. In other words, from a criminal point of view, the politics of criminal law is synonymous with the notion of "crime prevention policy with criminal law". Crime prevention efforts with criminal law are essentially part of law enforcement efforts (especially criminal law enforcement). Therefore, it is often said that politics or criminal law policies are part of law enforcement policies.[6] Crime prevention efforts through the making of criminal laws (laws) are essentially an integral part of community protection efforts. Therefore, it is natural that criminal law policies or politics are also an integral part of social policy.

Social policy can be interpreted as all rational efforts to achieve public welfare and at the same time include community protection. So in the sense of "social policy", it also includes "social welfare policy" and "social defense policy". Viewed from a broad sense, criminal law policies can cover the scope of policies in the field of material criminal law, in the field of formal criminal law and in the field of criminal law enforcement. So that the crime prevention policy is comprehensive in the framework of providing protection to the community to achieve public welfare. Overall what is meant is certainly not partial, meaning that crime prevention is not only oriented to how to punish criminals, but also how to provide protection to victims, the community and also the interests of the state as stated in the constitution (Article 28G paragraph (1) of the 1945 Constitution). This is where the real responsibility of the state as outlined in the constitution in
Article 28I paragraph (4) which confirms that the protection, promotion, enforcement and fulfillment of human rights is the responsibility of the state, especially the government/state judicial. As written basic law, the provisions in the constitution must of course be implemented by the legal products/statutory regulations under it. Crime prevention policies for the protection of personal, family and property under their control are part of human rights related to the state's duty to ensure how the proceeds of crime can be recovered or returned to those who are entitled to it by tracing and seizing the property from the perpetrators of the crime, including property used as a tool or means of committing a crime.

Confiscation of assets through criminal channels as regulated by the Criminal Procedure Code has encountered many obstacles. This is because according to the Criminal Procedure Code an asset can only be confiscated if the Public Prosecutor can prove the defendant's guilt and the asset is the result or means of a crime (confiscation is highly dependent on whether or not a defendant is proven) and cannot be carried out if the defendant cannot be presented at trial (died) run away, whereabouts unknown or permanently ill). Thus, the current concept in dealing with new crimes is oriented towards an approach to criminalizing criminals (follow the suspect) even though there is already a money laundering "regime" as well as provisions in the Corruption Crime Act alluding to the problem of confiscation of assets in circumstances where the defendant died and so on, but law enforcement is still oriented on how to prove the guilt or criminal responsibility of the perpetrators of the crime. Evidence in criminal law is more complicated because it seeks the material truth of an event, so that at this point sometimes with limited time and evidence to prove the relationship between wrongdoing and the proceeds of crime, many criminal assets cannot be confiscated either for the state or to be returned to victims of crime.[7]

Efforts to confiscate the proceeds of crime are one of the main concerns in tackling financial crimes in recent times. So, it is not without reason that the United Nations (UN) included the mechanism for confiscation of criminal assets as one of the norms in the United Nations Convention Against Corruption (UNCAC) in 2003. With the existence of this norm, states parties are required to to maximize all efforts to confiscate assets resulting from crimes without going through a criminal prosecution process.[8]

There are many difficulties/obstacles in uncovering corruption crimes with various modus operandi, making it a rational reason to criminalize certain optional provisions, such as the practice of illicit enrichment. In UNCAC, states parties are required to consider including this form of crime in the positive legal system of the state party, with this provision effectively recognizing the violation of "illicit enrichment".[9] With the same reasons 
and considerations, of course, it can also be a reason to introduce the concept of Unexplained wealth.

The Supreme Court (MA) has issued Supreme Court Regulation Number 1 of 2013 concerning Procedures for Settlement of Applications for Handling Wealth in the Crime of Money Laundering or Other Crimes. Background MA issued PERMA No. 1/2013 is that the Supreme Court is of the opinion that there is a void in the procedural law for the implementation of Article 67 of Law Number 8 of 2010 concerning the Prevention and Eradication of the Crime of Money Laundering, so it is necessary to establish a Supreme Court Regulation which regulates the procedural law for the handling of assets, while on the other hand, the Supreme Court has the authority to make regulations as a complement to fill legal deficiencies or voids in the course of the judiciary. In addition to the Law on Corruption Crimes, in principle, the Money Laundering Law has also made breakthroughs related to asset confiscation.

2. The concept of Illicit Enrichment and Unexplained Wealth in Non-Conviction Based Asset Forfeiture as a crime prevention policy in the justice system in Indonesia

We are all very aware that for crimes with economic motives or crimes that have "economical" value, the assets of criminal acts/criminal assets are "blood of the crime" for the continuation of the crime itself. In this context, it is not uncommon for us to hear news about many criminals who have been sentenced to prison, but they are still able to control crime from inside the prison. What is even more ironic is that prisons, which are predicted to be a place to train criminals to make people better, are actually used as safe places to control crime. With such a construction, more serious efforts are needed in combating and eradicating crime with a comprehensive perspective that combines a "suspect-oriented perspective" (criminal person/in personam) with a "profitoriented perspective" on criminal property (in rem or fructus sceleris), namely Eradication of crime is not only oriented to the perpetrators but also to the results of crimes obtained and controlled by the perpetrators of crime.

The perspective that is oriented towards crime proceeds is the development of a fundamental idea of justice which states "crime does not pay". This fundamental idea of justice is the same as the doctrine of "unjust enrichment" in an agreement or the doctrine in the adage ex turpi causa non oritur (a cause that is not lawful does not lead to a claim) is known in the agreement. We can find this doctrine in Article 1320 of the Civil Code, on the condition "a lawful cause" as one of the conditions for the validity of an agreement. In eradicating crime, it is based on the understanding that the proceeds of any crime (economic in nature) as well as losses from crime and whoever becomes a victim of the crime, the state must be present to recover it with comprehensive legal instruments, both in the form of material and formal law, both through criminal and legal mechanisms. civil law or a combination of these mechanisms, such as the in rem mechanism with a criminal "style".

So far, the mechanism with a "suspect-oriented perspective" (criminal person/in person) orientation is considered sufficient with the existing legal apparatus. For this reason, the focus of this study is a new mechanism, namely with a civil "style" (Non-Conviction Based (NCB) asset forfeiture/in rem/profit-oriented perspective") with a criminal nuance or still in contact with criminal. The NCB mechanism (lawsuit in rem or lawsuit against assets) is expected to be a powerful tool to confiscate and expropriate assets, not only criminal acts of corruption but also criminal acts with other economic motives which have now developed and become increasingly complex because the perpetrators are educated and transnational or cross a country that produces a lot of illegal wealth.

Regarding the asset confiscation mechanism, the United Nations Convention Against Corruption (UNCAC, 2003) has regulated it in several articles where the seizure of assets of perpetrators of criminal acts of corruption can be carried out through criminal and civil channels NonConviction Based (NCB) Asset Forfeiture (in rem), can also be returned directly through a court process based on a "negotiation plea" or "plea bargaining system" system and through indirect returns, namely through a confiscation process based on a court decision (Article 53 to Article 57 UNCAC). The Non-Conviction Based (NCB) mechanism for asset forfeiture certainly needs to be developed, not only limited to corruption, but also to other criminal acts as within the scope of money laundering.

Confiscation of assets without punishment (NCB) is a fundamental concept in efforts to eradicate criminal acts that are detrimental to the state's finances and economy, by withdrawing the property of the perpetrator suspected of having obtained from a crime that is detrimental to the state's finances or economy. These crimes can be sourced from corruption crimes, illegal logging crimes, narcotics crimes, customs and excise crimes, as well as money laundering crimes.[10]

Meanwhile, according to Yenti Garnasih, the most appropriate and simple way to carry out the NCB asset forfeiture mechanism is that initially assets suspected of being the proceeds of crime are blocked and withdrawn from economic traffic, namely through confiscation requested by the court. Furthermore, the property is declared as tainted property by a court decision. After being declared as tainted property, the court makes an announcement through media that can be accessed and known by the public for a sufficient period of time, which is approximately 30 (thirty) days. This period of time is considered sufficient for third parties to know that the court will seize assets. If within that period of time there 
is a third party who objected to the act of confiscation, the third party may file a challenge to the court and bring valid evidence to prove that he is the owner of the property by explaining how the property was acquired.[11]

There are two relatively new concepts in the confiscation of criminal assets without punishment/NonConviction Based (NCB), namely illicit enrichment and unexplained wealth. This concept was born because it is not easy for law enforcement officers to prove the existence of corrupt practices carried out by state officials in order to obtain their wealth because the conventional criminal law proving process has high/strict standards. Meanwhile, the principle used in examining allegations of illicit enrichment and unexplained wealth is deductive logic: the investigation is carried out on the alleged proceeds of a crime, not on the (initial) crime committed. In other words, what is being examined is the "smoke" (unnatural wealth), not the "fire" (criminal acts that allow the existence of unnatural wealth) because that is one of the key concepts of Illicit Enrichment is the application of the inverse method of proof and the standard of proof that lower so that it can minimize various criminal acts (not only corruption and sich) but also other serious crimes such as drugs, illegal logging, illegal mining, tax evasion and so on.[12]

Unexplained Wealth was practically different from Illicit Enrichment. Where the concept of unexplained subject setting is wider than the Illicit Enrichment. Illicit Enrichment is only for public officials while unexplained wealth is for everyone. The accountability process in illicit enrichment is only through a criminal mechanism, while in unexplained wealth, it can also be requested in a civil manner to confiscate unexplained assets. Currently, the countries that practice unexplained wealth are Australia and the Philippines which regulate unexplained wealth but the essence is illicit enrichment. On the other hand, illicit enrichment and unexplained wealth have a different basis for thinking between the two.[13]

According to Yunus Husein[14], who in 2012 served as Head of the Center for Financial Transaction Reports and Analysis (PPATK), Australia generally defines unexplained wealth as a legal instrument that allows the confiscation of a person's assets or property which is very large in amount but is considered unreasonable because it is not in accordance with the source of income and the person concerned is unable to prove (through the reverse method of proof) that the property was legally obtained or not from a criminal act. In the event that a person has unexplained wealth, the amount of property that cannot be proven to have been obtained legally can be confiscated by the State through a certain legal procedure. Meanwhile, the remaining assets that can be proven legally obtained can be controlled and enjoyed again by the owner.
The application of asset forfeiture for those who have unexplained wealth is considered one of the most likely ways to discourage these practices. This is because the process of proving unexplained wealth is easier because:

a. Using the reverse verification procedure even though the Public Prosecutor still has to prove the existence of an amount of wealth that is considered unreasonable; and

b. Using the standard of civil evidence, namely the balance of probability, which is light or low compared to the standard of criminal proof (beyond reasonable doubt).

The use of this standard of civil evidence is due to the process of confiscation of unexplained wealth assets, as well as other non-criminal confiscation processes (NCB asset forfeiture) carried out through civil processes, not criminal because the object is the goods (in rem) that you want to confiscate, not the punishment of the person.

The results of Indonesia Corruption Watch's research on the Implementation and Regulation of Illicit Enrichment (Illegal Wealth Increase) in Indonesia stated that currently out of 193 countries in the world, there are at least 44 countries that have legal instruments at the level of the law regarding illicit enrichment, some countries that have regulated in the Act, namely India, Guyana, Sierra Leone and China. The definition of illicit enrichment in the 4 countries is more or less the same, namely about illegal wealth. The difference between the countries is only in the translation of the significantly different forms of assets that are used to measure income.[15]

The confiscation of proceeds and instruments of criminal acts, in addition to reducing or eliminating the economic motives of criminals, can also have the effect of breaking the chain of crime and can increase public confidence in the law enforcement process, especially in the protection of assets that are "taken/confiscated/controlled" by criminals. can be confiscated by the state through law enforcement officers to be returned to those who are entitled. This can then be referred to as an effort to prevent and eradicate crime as a whole in Indonesia.

The idea to study this is based on or motivated by a reality or many facts from the news that many criminals who still exist commit crimes/enjoy their crimes even though criminally they have been sentenced and served imprisonment. The need for illicit enrichment and unexplained wealth arrangements is considered very important as a rational effort in preventing and eradicating crime as well as providing protection to the community including the state, which in the end is expected to have an impact on effectiveness in terms of justice, certainty and benefit in law enforcement. 


\section{IV.CONCLUSION}

The concept of Illicit Enrichment and Unexplained Wealth in Non-Conviction Based Asset Forfeiture is still a new thing in law enforcement. When examined from the formulation of the problem and associated with possible existing and future obstacles, it can be tested with existing facts so that a conclusion can be drawn from the phenomena that occur based on existing premises where for the prevention of crime, property or assets of criminal acts must be confiscated to break the chain of criminal acts, especially criminal acts with an economic motive or to gain profit for the perpetrators of criminal acts, by confiscation of assets that are not reasonable from the perpetrators of the crime. However, existing regulations are not sufficient to support asset confiscation efforts.

The measure of the performance of law enforcement officers still prioritizes the achievement of performance following the suspect (related to the mindset and orientation or culture of law enforcement) so that there are difficulties in confiscation of assets through or under criminal confiscation. Although Indonesia has ratified UNCAC 2003, the provisions of Illicit Enrichment as regulated in Article 20 of UNCAC have not been realized by lawmakers in the form of regulations.

Thus, there is a need for a criminal law policy or criminal law politics in overcoming criminal acts related to criminal assets by establishing regulations regarding confiscation of Non Conviction Based (NCB) property confiscation (in rem) based on aspects of certainty (rechtssicherheit), justice (gerechtigkeit) and legal benefits (zweckmassigheit) while prioritizing the values contained in human rights.

\section{REFERENCES}

[1] Harry Ponto, Surga Para Koruptor, Kompas, Jakarta, 2004.

[2] Soerjono Soekanto, Faktor-Faktor Yang Mempengaruhi Penegakan Hukum, Cet. 3, Radja Grafindo Persada, Jakarta. 1993.

[3] Mardjono Reksodiputro, Manajemen Penegakan Hukum dan Sistem Peradilan Pidana "Apa Pokok Masalah? (A Conceptual and Theoretical Understanding) disampaikan sebagai Kuliah di Sespim Polri Dikreg 47, Lembang, Bandung, 21 October 2008

[4] Fred N. Kerlinger in Amirudin, Zainal Asikin, Pengantar Metode Penelitian Hukum, PT. Raja Grafindo Persada, Jakarta, 2004.

[5] Amiruddin, Pengantar Metode Penelitian Hukum, Jakarta: RajaGrafindo Persada.2004.

[6] Barda Nawawi Arief, Antologi Kebijakan Hukum Pidana, Perkembangan Penyusunan Rancangan KUHP Baru. Lihat juga, Lilik Mulyadi, Antologi Hukum Pidana, Perspektif, Teoritis dan Praktek, Bandung : PT. Alumni, 2008.

[7] Achmad Ali, Runtuhnya Hukum di Indonesia, Jakarta: Ghalia Indonesia, 2002.

[8] Refki Saputra, "Tantangan Penerapan Perampasan Aset Tanpa Tuntutan Pidana (Non-Conviction Based Asset Forfeiture) Dalam RUU Perampasan Aset Di Indonesia”, 16 Juni 2017.

[9] Muhammad Yusuf, Merampas Aset Koruptor (Solusi Pemberantasan Korupsi di Indonesia), buku Kompas, Jakarta, 2013.

[10]David Fredriek Albert Porajow, Non-Conviction Based Asset Forfeiture Sebagai Alternatif Memperoleh Kembali Kekayaan Negara yang Hilang Karena Tindak Pidana yang Berkaitan dengan Perekonomian Negara, Tesis Program Pascasarjana Magister Hukum FHUI, Jakarta: Universitas Indonesia, 2013.

[11] Yenti Garnasih, "Asset Recovery Act sebagai strategi dalam pengembalian aset hasil korupsi, dalam Perampasan Aset Hasil
Tindak Pidana," Jurnal Legislasi Indonesia, Vol.7 No.4, Desember 2010.

[12] Anti Corruption Resource Center Team, "Legal Responses to Corruption" in www.u4.no/themes/uncac/report.cfm.

[13] Alvon Kurnia Palma, dkk, "Implementasi dan Pengaturan Illicit Enrichment (Peningkatan Kekayaan Secara Tidak Sah) di Indonesia", Indonesia Corruption Watch, 2014.

[14] Yunus Husein, "Perampasan Aset Tanpa Pemidanaan Dalam Perkara Tndak Pidana Korupsi” Pusat Studi Hukum dan Kebijakan Indonesia (PSHK), Jakarta, 2010.

[15] Indonesia Corruption Watch, Implementasi dan Pengaturan Illicit Enrichment (Peningkatan Kekayaan Secara Tidak Sah) di Indonesia, Policy Paper, 2014. 